\title{
Synthetic anthocyanidins and their antioxidant properties
}

\author{
Homar S. Barcena*, Peishan Chen and Abraham Tuachi
}

\begin{abstract}
Anthocyanidins were synthesized to study the effect of methoxy substitution on the B ring to their antioxidant property. Comparative FRAP studies show 2'- and 4'-methoxy substituents have higher antioxidant activities, which may be attributed to both resonance and inductive effects.
\end{abstract}

Keywords: Dyes, Green chemistry, FRAP, One pot synthesis

\section{Background}

Anthocyanidins are pigments that are associated with the bright coloration of flowers and fruits. These natural dyes belong to the flavonoid family, with their basic structure comprising of an aromatic ring (A) fused with an heterocyclic ring containing an oxygen (C), which is also bonded to a third aromatic ring (B). These compounds are normally substituted with hydroxy groups, which help stabilize the charge on the flavylium cation. When one of the phenols is substituted with glycosides, the compound is called an anthocyanin.

The natural occurrence of anthocyanins and anthocyanidins warrants their study not only for the evolutionary advantage they confer to plants, but also for their potential applications (Castañeda-Ovando et al. 2009). Besides their utility as colorants for foods and cosmetics (Campanella et al. 2010), they are also explored in materials science (Pina et al. 2012) for example, as photosensitizers for photovoltaics (Calogero et al. 2013; Gokilamani et al. 2013), and as molecular logic gates (Pina et al. 1998). Like many polyphenols, they exhibit biological activities that are beneficial to human health (Pojer et al. 2013) such as in glucose metabolism (Alzaid et al. 2013), protection against cardiovascular disease (Wallace 2011), and mediation of oxidative stress (Zafra-Stone et al. 2007). Their putative roles in human pathologies are of interest, particularly in cancer prevention (Wang and Stoner

\footnotetext{
*Correspondence: homar.barcena@kingsborough.edu Physical Sciences, Kingsborough Community College, Brooklyn, NY 11235, USA
}

2008; Cooke et al. 2005). Despite their biological significance, their pharmacokinetics in humans remains largely unexplored (Kay 2006). Thus, to further the utility of anthocyanins in therapeutics and gain an understanding of their activities as applied to drug design, we synthesized anthocyanidins 1-3 and studied their antioxidant properties.

There are several methods for determining and expressing antioxidant activity, particularly for natural anthocyanins extracted from plants (Thaipong et al. 2006; Huang et al. 2005; Pulido et al. 2000; Sochor et al. 2010). This paper reports the preparation and characterization of three new anthocyanidins with different substitution patterns on the $B$ ring. The antioxidant activities of the synthetic anthocyanidins were studied using a modified ferric reducing activity of plasma (FRAP) assay (Benzie and Strain 1996, 1999).

\section{Results and discussion}

Synthesis of the flavylium cation occurs under harsh conditions (Balaban et al. 1969) and preparations of anthocyanidins have been achieved by bubbling the reaction with hydrogen chloride gas (Moncada et al. 2004), treatment with perchloric acid (Sato et al. 1999; Dorofeenko and Olekhnovich 1972), or employment of corrosive Lewis acids such as boron trifluoride etherate (Kuhnert et al. 2001). Recently, milder synthesis using sulfuric acid was reported (Calogero et al. 2013), and described herein is a convenient approach to obtaining anthocyanidins, using less solvent and shorter reaction times. A summary of synthetic methods is listed

\section{Springer}

(c) 2015 Barcena et al. This article is distributed under the terms of the Creative Commons Attribution 4.0 International License (http://creativecommons.org/licenses/by/4.0/), which permits unrestricted use, distribution, and reproduction in any medium, provided you give appropriate credit to the original author(s) and the source, provide a link to the Creative Commons license, and indicate if changes were made. 
in Table 1 and the synthesis of flavylium ring has been comprehensively reviewed elsewhere (Iacobucci and Sweeny 1983).

Scheme 1 shows the condensation of 2,4-dihydroxybenzaldehyde with different acetophenone derivatives using a minimum amount of acetic and sulfuric acid. Heating in a water bath for $30 \mathrm{~min}$ facilitated the reaction, which resulted in a dark viscous liquid. The products were purified by trituration with diethyl ether. When performed with minimum exposure to air, fine, brightly colored powders are obtained, which were dried further in a vacuum desiccator. The hygroscopic anthocyanidins were assumed to be bisulfate salts, and the yields were 92-95\%. While the use of concentrated sulfuric acid is still harsh, improvements such as shorter heating time, use of the renewable solvent acetic acid, minimum solvents and adjuvants used during purification, and high yields makes our procedure greener. Characterization by ${ }^{1} \mathrm{H}$ and ${ }^{13} \mathrm{C}$ NMR and HRMS confirms the products, which have nearly similar UV-Vis and IR spectra in the functional group region.

Solutions of 1-3 were prepared by first dissolving in DMF, and subsequent dilution with acetate buffer $(\mathrm{pH}$ 3.6). Flavylium salts are in equilibrium with their hydrates in aqueous solutions, with low $\mathrm{pH}$ favoring the non-hydrated pyrilium cation (Moncada et al. 2004). Once hydrated, they may undergo ring opening, then tautomerization to the enone, and further isomerization to give trans chalcones. Buffered solutions of 1-3 showed no variation in the UV spectra when kept in the dark, and when kept cold for at least 1 week, hinting on their stability.

A modified FRAP assay was used to study the antioxidant properties of 1-3. Freshly prepared FRAP reagent was admixed with antioxidants at room temperature, which showed rapid development of color characteristic of the formation of the $\mathrm{Fe}^{2+}$ complex. Spectrophotometric measurements were taken 2 min after mixing and all studies were performed in triplicate. The initial color change was fast, however the redox reaction continued for longer than $15 \mathrm{~min}$, similar to what has been observed in polyphenol antioxidants (Pulido et al. 2000). Varying the location of the methoxy substituent on the $\mathrm{C}$ ring offers slight differences in the reducing power of the synthesized flavylium salt, with 1 showing the highest antioxidant activity (Fig. 1). This may be attributed to the added stability conferred by conjugation with the $B$ ring substituents (Calogero et al. 2013). It can be reasoned that the higher activity of $\mathbf{1}$ compared to $\mathbf{3}$ is due to inductive effects of the proximal $2^{\prime}$ methoxy to the

Table 1 Reported syntheses of anthocyanidins

\begin{tabular}{|c|c|c|}
\hline Conditions & Yield (\%) & References \\
\hline $\begin{array}{l}\text { Salicylaldehyde, acetophenone, } \mathrm{HBF}_{4}, \mathrm{HOAc} \text {, acetic anhydride, } 60^{\circ} \mathrm{C} \text {, } \\
12 \mathrm{~h}\end{array}$ & $40-58,23-78$ & Katritzky et al. (1998), Gomes et al. (2009) \\
\hline Salicylaldehyde, acetophenone, $\mathrm{BF}_{3}$ etherate, neat & 81 & Kuhnert et al. (2001) \\
\hline Salicylaldehyde, acetophenone, $\mathrm{H}_{2} \mathrm{SO}_{4}, \mathrm{HOAc}$, overnight & $40-88$ & Calogero et al. (2013) \\
\hline Salicylaldehyde, acetophenone, EtOAc, $\mathrm{HCl}$ gas, $0^{\circ} \mathrm{C}, 3$ days & $56-75,55-84$ & Mora-Soumille et al. (2013), Mas (2003) \\
\hline Salicylaldehyde, acetophenone, $\mathrm{HPF}_{6}{ } \mathrm{HOAC}_{2} 2$ days & 89 & Kueny-Stotz et al. (2008) \\
\hline Salicylaldehyde, acetophenone, $\mathrm{HCl}$ gas, formic acid, 5 h & 56 & Moncada et al. (2004), Michaelidis and Wizinger (1951) \\
\hline Salicylaldehyde, benzaldehyde, ethyl chloroformate, $\mathrm{HClO}_{4}, 1-12 \mathrm{~h}$ & 49-95 & Sato et al. (1999) \\
\hline Salicylideneacetophenone, $\mathrm{HBF}_{4} \mathrm{OEt}_{2}$ or $\mathrm{HOTf}$ in $\mathrm{Et}_{2} \mathrm{O}$ & $62-67$ & Fichtner et al. (2001) \\
\hline Phenol, arylethynylketone, $\mathrm{HPF}_{6}, \mathrm{HOAc}$, r.t. & 82-99 & Kueny-Stotz et al. (2007) \\
\hline
\end{tabular}<smiles>[Y4]c1ccc(C(C)=O)c([Y4])c1[X]</smiles>

$$
\begin{aligned}
& \text { 1: } X_{1}=H, X_{2}=H, X_{3}=\text { OMe }(97 \%) \\
& \text { 2: } X_{1}=H, X_{2}=O M e, X_{3}=H(99 \%) \\
& \text { 3: } X_{1}=O M e, X_{2}=H, X_{3}=H(98 \%)
\end{aligned}
$$

Scheme 1 Synthesis of anthocyanidins 1-3 


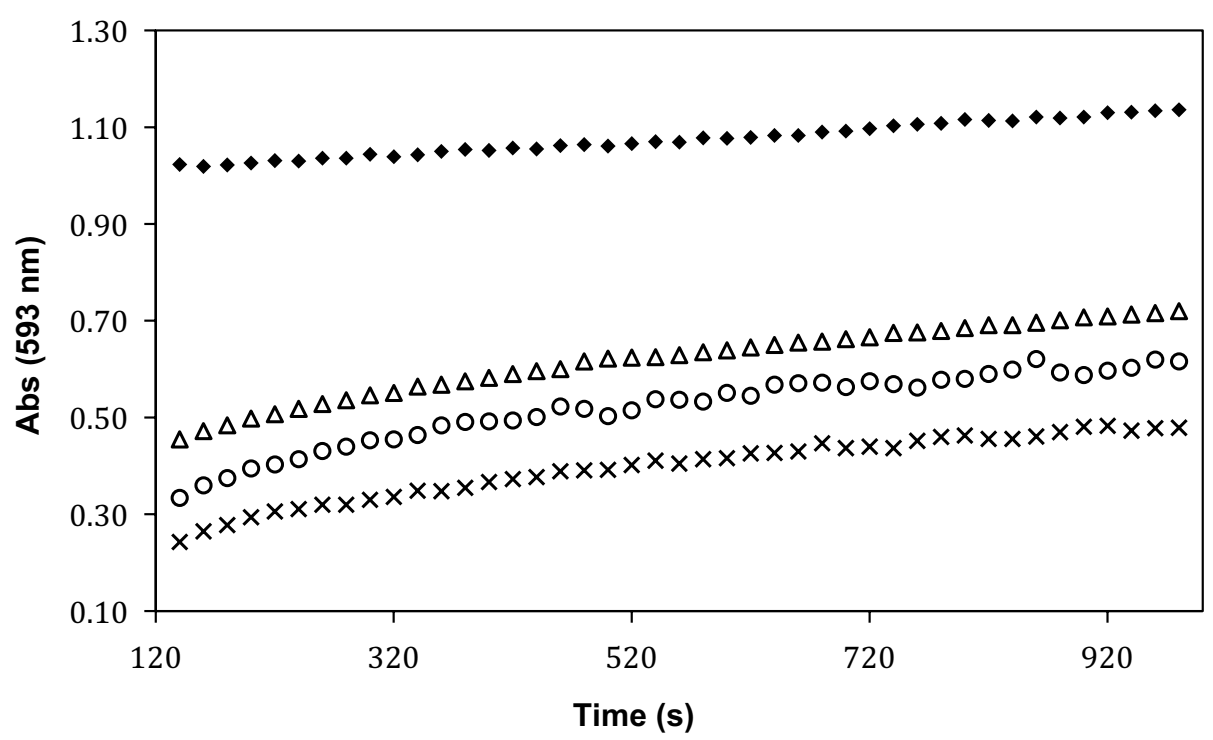

Fig. 1 FRAP assay of synthetic anthocyanidin 1 (open triangle), 2 (multiplication sign), and $\mathbf{3}$ (open circle). Vitamin C (filled diamond) shows higher antioxidant activity under similar conditions. The antioxidants are of the same final concentration $(0.15 \mathrm{mM})$, and the final concentration of $\mathrm{Fe}^{3+}(\mathrm{TPTZ})_{2}$ was $735 \mathrm{mM}$

flavylium oxygen, which is absent in the $4^{\prime}$ methoxy (see Additional files 1,2). The resonance effect is absent for the $3^{\prime}$ methoxy, resulting in least stable derivative (2).

The solution chemistry of anthocyanidins is complex (Pina et al. 2012) and analogous anthocyanidins under similar $\mathrm{pH}$ exist in equilibrium between the flavylium ion, deporotonated quinoidal base, and as the hydrated hemiketal (Brouillard et al. 1982; Sweeny and Iacobucci 1983). The FRAP assay is non-specific for any antioxidant present under the reaction conditions that could reduce $\mathrm{Fe}^{3+}$, which takes into account the chemistry flavylium ions undergo in solution. Under similar assay conditions, ascorbic acid gives higher FRAP value (2.7) and shows a higher antioxidant activity than anthocyanidins 1-3. FRAP values are normally obtained after $4 \mathrm{~min}$ at $37^{\circ} \mathrm{C}$, or 6 min at room temperature. No significant variation of the FRAP value was observed between 4 and 6 min for our experiments, which are 2.2, 2.0, and $2.1 \mathrm{mM}$ for $\mathbf{1}$, 2, 3, respectively, based on equivalent $\mathrm{FeSO}_{4}$ standard. In comparison, purified anthocyanin extracts from fruit show reducing power one-third that of ascorbic acid, however these comparisons are not straightforward because the reducing power is dose-dependent even for ascorbic acid (Sun et al. 2014).

\section{Conclusion}

In conclusion, we demonstrate a greener synthesis of anthocyanidins, which allows facile purification by trituration. This facilitates the study of the effects of various substituents on the different rings to the properties of anthocyanidins. In this case, we show that altering the location of the methoxy substituent on the $B$ ring results in slight variations in the resultant antioxidant activity, as measured by the FRAP assay. The methoxy substituent on the $2^{\prime}$ position of the $B$ ring stabilizes the radical formed in the 7-OH position by conjugation, and by inductive effects due to the proximity of the the methoxy group to the pyrilium oxygen. These results demonstrate the feasibility of tailoring the redox properties of synthetic anthocyanidins.

\section{Experimental}

All starting materials and solvents were purchased from commercial sources. NMR analyses were performed using a Bruker $400 \mathrm{MHz}$ Avance, and IR analyses were performed using a Bruker Alpha ATR-IR. High-resolution mass spec were obtained from The City College of New York Mass Spectrometry Facility, and the counter anion was not included in the molecular ion peak calculations.

\section{General procedure for FRAP}

Freshly prepared FRAP solution was prepared by mixing acetate buffer at $\mathrm{pH} 3.6\left(10.0 \mathrm{~cm}^{3}, 20 \mathrm{mM}\right)$, TPTZ solution $\left(1.0 \mathrm{~cm}^{3}, 10 \mathrm{mM}\right)$, and $\mathrm{FeCl}_{3}$ solution $\left(1.0 \mathrm{~cm}^{3}\right.$, $10 \mathrm{mM})$ in a vial. Stock solutions of the anthocyanidins $(35.0 \mathrm{mg})$ were prepared in DMSO $\left(100 \mathrm{~cm}^{3}, 1 \mathrm{mM}\right)$. All solutions were sparged with $\mathrm{N}_{2}$ prior to each experiment. For each experiment, the stock was diluted to $0.5 \mathrm{mM}$ with acetate buffer and equilibrated for $3 \mathrm{~min}$. The 
experiment was initiated in a new vial containing de-ionized water $(900 \mu \mathrm{L})$ and TPTZ solution $\left(9.0 \mathrm{~cm}^{3}\right)$. To this was added the diluted anthocyanidins $(300 \mu \mathrm{L})$, mixed, and immediately transferred to a cuvette. Data capture was started exactly 2 min after the reaction was initiated. The blank was prepared similarly, but adding only buffer instead of the stock anthocyanidin solution. Each experiment was repeated at least three times.

\section{General procedure for anthocyanidins}

To a $25-\mathrm{cm}^{3}$ round bottomed flask was added 2,4-dihydroxybenzaldehyde (414 $\mathrm{mg}, 3.00 \mathrm{mmol}$ ) and the corresponding methoxyacetophenone isomer $\left(0.413 \mathrm{~cm}^{3}\right.$, $3.00 \mathrm{mmol})$. The mixture was dissolved in acetic acid $\left(1.00 \mathrm{~cm}^{3}\right)$, and sulfuric acid $\left(0.500 \mathrm{~cm}^{3}\right)$ was added. The mixture was equipped with an air condenser and heated in a boiling water bath for $30 \mathrm{~min}$. The solid product was obtained by triturating the oil with diethyl ether $\left(2.0 \mathrm{~cm}^{3}\right)$. Purification was achieved by dissolving the crude in acetic acid and triturating with ether at least three times. The product was vacuum filtered and washed with diethyl ether before drying in a vacuum desiccator.

7-hydroxy-2-(2-methoxyphenyl)chromenylium hydrogen sulfate (1, $\mathrm{C}_{16} \mathrm{H}_{14} \mathrm{O}_{7} \mathrm{~S}$ ) Rust-colored powder, $0.994 \mathrm{~g}$ (95 \%). M.p.: $100-107{ }^{\circ} \mathrm{C}$ (decomposed); ${ }^{1} \mathrm{H}$ NMR $\left(400 \mathrm{MHz}, \mathrm{MeOH}-\mathrm{d}_{4}\right) \delta=9.2(\mathrm{~d}, 1 \mathrm{H}, J=8.7 \mathrm{~Hz}), \delta=8.7$ $(\mathrm{d}, 2 \mathrm{H}, J=8.7 \mathrm{~Hz}), \delta=8.4(\mathrm{dd}, 1 \mathrm{H}, J=8.08,1.6 \mathrm{~Hz})$, $\delta=8.2(\mathrm{~d}, 1 \mathrm{H}, J=9.0 \mathrm{~Hz}), \delta=7.8(\mathrm{td}, 1 \mathrm{H}, J=7.9,1.6 \mathrm{~Hz})$, $\delta=7.51(\mathrm{~d}, 1 \mathrm{H}, J=1.6 \mathrm{~Hz}), \delta=7.48(\mathrm{dd}, 1 \mathrm{H}, J=9.0$, $2.2 \mathrm{~Hz}), \delta=7.38(\mathrm{~d}, 1 \mathrm{H}, J=8.6 \mathrm{~Hz}), \delta=7.3(\mathrm{~m}, 1 \mathrm{H}), \delta 4.1$ $(\mathrm{s}, 3 \mathrm{H}) ;{ }^{13} \mathrm{C}$ NMR $\left(100 \mathrm{MHz}, \mathrm{MeOH}-\mathrm{d}_{4}\right) \delta 170.3,170.0$. $161.1,160.3,154.5,137.8,132.8,131.0,122.1,121.7$, 119.9, 117.8, 117.0, 113.0, 102.155 .6 ppm; HRMS (ESI) $m / z 253.0897\left(\mathrm{M}^{+}\right)$, calcd for $\mathrm{C}_{16} \mathrm{H}_{13} \mathrm{O}_{3} 253.0865$.

7-hydroxy-2-(3-methoxyphenyl)chromenylium hydrogensulfate (2, $\left.\mathrm{C}_{16} \mathrm{H}_{14} \mathrm{O}_{7} \mathrm{~S}\right) \quad$ Dark red powder, $0.966 \mathrm{~g}(92 \%)$. M.p.: $122-155{ }^{\circ} \mathrm{C}$ (decomposed); ${ }^{1} \mathrm{H}$ NMR $(400 \mathrm{MHz}$, $\left.\mathrm{MeOH}-\mathrm{d}_{4}\right) \delta=9.3(\mathrm{~d}, 1 \mathrm{H}, J=8.5 \mathrm{~Hz}), \delta=8.5(\mathrm{~d}, 1 \mathrm{H}$, $J=8.5 \mathrm{~Hz}), \delta=8.3(\mathrm{~d}, 1 \mathrm{H}, J=9.0 \mathrm{~Hz}), \delta=8.1(\mathrm{~d}, 1 \mathrm{H}$, $J=8.2 \mathrm{~Hz}), \delta=8.0(\mathrm{~s}, 1 \mathrm{H}), \delta=7.64(\mathrm{~m}, 1 \mathrm{H}), \delta=7.62$ $(\mathrm{d}, 1 \mathrm{H}, J=1.8 \mathrm{~Hz}), \delta=7.5(\mathrm{dd}, 1 \mathrm{H}, J=9.0,2.1 \mathrm{~Hz})$, $\delta=7.4(\mathrm{dd}, 1 \mathrm{H}, J=8.3,1.9 \mathrm{~Hz}), \delta=4.0(\mathrm{~s}, 3 \mathrm{H}) ;{ }^{13} \mathrm{C}$ NMR (100 MHz, MeOH-d $) \delta 171.9,170.6,160.9,160.2$, $155.1,133.1,131.0,130.5,122.5,121.8,121.4,120.5$, $113.4,113.1,102.3,55.0$ ppm; HRMS (ESI) $m / z 253.0890$ $\left.\left(\mathrm{M}^{+}\right)^{+}\right)$, calcd for $\mathrm{C}_{16} \mathrm{H}_{13} \mathrm{O}_{3} 253.0865$.

7-hydroxy-2-(4-methoxyphenyl)chromenylium hydrogensulfate (3, $\mathrm{C}_{16} \mathrm{H}_{14} \mathrm{O}_{7} \mathrm{~S}$ ) Orange-red powder, $0.990 \mathrm{~g}$ (95 \%). M.p.: $157-190{ }^{\circ} \mathrm{C}$ (decomposed); ${ }^{1} \mathrm{H}$ NMR $\left(400 \mathrm{MHz}, \mathrm{MeOH}-\mathrm{d}_{4}\right) \delta=9.1(\mathrm{~d}, 1 \mathrm{H}, J=8.7 \mathrm{~Hz}), \delta=8.5$ $(\mathrm{d}, 2 \mathrm{H}, J=9.1 \mathrm{~Hz}), \delta=8.4(\mathrm{~d}, 1 \mathrm{H}, J=8.7 \mathrm{~Hz}), \delta=8.2(\mathrm{~d}$, $1 \mathrm{H}, J=9.0 \mathrm{~Hz}), \delta=7.5(\mathrm{~d}, 1 \mathrm{H}, J=2.0 \mathrm{~Hz}), \delta=7.4(\mathrm{dd}$, $1 \mathrm{H}, J=8.9,2.2 \mathrm{~Hz}), \delta=7.3(\mathrm{~d}, 2 \mathrm{H}, J=9.1 \mathrm{~Hz}), \delta=4.0$ $(\mathrm{s}, 3 \mathrm{H}) ;{ }^{13} \mathrm{C}$ NMR $\left(100 \mathrm{MHz}, \mathrm{MeOH}-\mathrm{d}_{4}\right) \delta$ 173.7, 170.8, 168.7, 160.1 155.2, 143.2, 133.6, 122.83, 122.76, 120.6, 117.2, 113.7, 103.8, 57.0 ppm; HRMS (ESI) $m / z 253.0889$ $\left(\mathrm{M}^{+}\right)$, calcd for $\mathrm{C}_{16} \mathrm{H}_{13} \mathrm{O}_{3} 253.0865$.

\section{Additional files}

Additional file 1. Checklist for compound characterization.

Additional file 2. Compound characterization data

\section{Abbreviation}

FRAP: ferric reducing activity of plasma.

\section{Authors' contributions}

HSB drafted the manuscript and performed synthesis. PC performed synthesis and characterization. AT performed FRAP assays.

\section{Acknowledgements}

We are grateful to PSC-CUNY Cycle 41 and the CUNY Office of Vice Chancellor for Research (General Research Initiative 2011) for financial support. We are grateful to Dr. Lijia Yang and the LC-MS Lab at City College, CUNY for mass spectral analyses.

\section{Compliance with ethical guidelines}

\section{Competing interests}

The authors declare that they have no competing interests.

Received: 16 May 2015 Accepted: 14 August 2015

Published online: 17 September 2015

\section{References}

Alzaid F, Cheung H-M, Preedy VR, Sharp PA (2013) Regulation of glucose transporter expression in human intestinal Caco-2 Cells following exposure to an anthocyanin-rich berry extract. PLoS One 8(11):e78932. doi:10.1371/ journal.pone.0078932

Balaban AT, Schroth W, Fischer G (1969) Pyrylium salts part I. Syntheses. In: Katritzky AR, Boulton AJ (eds) Advances in heterocyclic chemistry, vol 10. Academic Press, pp 241-326. doi:10.1016/S0065-2725(08)60499-7

Benzie IFF, Strain JJ (1996) The ferric reducing ability of plasma (FRAP) as a measure of antioxidant power: the FRAP assay. Anal Biochem 239(1):7076. doi:10.1006/abio.1996.0292

Benzie IFF, Strain JJ (1999) [2] Ferric reducing/antioxidant power assay: direct measure of total antioxidant activity of biological fluids and modified version for simultaneous measurement of total antioxidant power and ascorbic acid concentration. In: Lester P (ed) Methods in enzymology, vol 299. Academic Press, pp 15-27. doi:10.1016/ S0076-6879(99)99005-5

Brouillard R, lacobucci GA, Sweeny JG (1982) Chemistry of anthocyanin pigments. 9. UV-visible spectrophotometric determination of the acidity constants of apigeninidin and three related 3-deoxyflavylium salts. J Am Chem Soc 104(26):7585-7590. doi:10.1021/ja00390a033

Calogero G, Sinopoli A, Citro I, Di Marco G, Petrov V, Diniz AM, Parola AJ, Pina F (2013) Synthetic analogues of anthocyanins as sensitizers for dye-sensitized solar cells. Photochem Photobiol Sci 12(5):883-894. doi:10.1039/ C3PP25347C 
Campanella A, Rustoy E, Baldessari A, Baltanás MA (2010) Lubricants from chemically modified vegetable oils. Bioresour Technol 101(1):245-254. doi:10.1016/j.biortech.2009.08.035

Castañeda-Ovando A, Pacheco-Hernández MDL, Páez-Hernández ME, Rodríguez JA, Galán-Vidal CA (2009) Chemical studies of anthocyanins: a review. Food Chem 113(4):859-871. doi:10.1016/j.foodchem.2008.09.001

Cooke D, Steward WP, Gescher AJ, Marczylo T (2005) Anthocyans from fruits and vegetables-does bright colour signal cancer chemopreventive activity? Eur J Cancer 41(13):1931-1940. doi:10.1016/j.ejca.2005.06.009

Dorofeenko GN, Olekhnovich LB (1972) Synthesis of pyrylium salts by condensation of benzalacetophenone with aliphatic carbonyl compounds. Chem Heterocycl Compd 8(7):800-802. doi:10.1007/BF00475205

Fichtner C, Remennikov G, Mayr H (2001) Kinetics of the reactions of flavylium ions with $\pi$-nucleophiles. Eur J Org Chem 2001(23):4451-4456. doi:10.1002/1099-0690(200112)2001:23<4451::AID-EJOC4451>3.0.CO;2-F

Gokilamani N, Muthukumarasamy N, Thambidurai M, Ranjitha A, Velauthapillai D (2013) Utilization of natural anthocyanin pigments as photosensitizers for dye-sensitized solar cells. J Sol-Gel Sci Technol 66(2):212-219. doi:10.1007/s10971-013-2994-9

Gomes R, Diniz AM, Jesus A, Parola AJ, Pina F (2009) The synthesis and reaction network of 2-styryl-1-benzopyrylium salts: an unexploited class of potential colorants. Dye Pigment 81(1):69-79. doi:10.1016/j.dyepig.2008.09.007

Huang D, Ou B, Prior RL (2005) The chemistry behind antioxidant capacity assays. J Agric Food Chem 53(6):1841-1856. doi:10.1021/jf030723c

lacobucci GA, Sweeny JG (1983) The chemistry of anthocyanins, anthocyanidins and related flavylium salts. Tetrahedron 39(19):3005-3038. doi:10.1016/S0040-4020(01)91542-X

Katritzky AR, Czerney P, Levell JR, Du W (1998) Molecular engineering of benzo[b]pyrylium salts by indirect electrophilic substitution. Eur J Org Chem 1998(11):2623-2629. doi:10.1002/ (SICI)1099-0690(199811)1998:11<2623::AID-EJOC2623>3.0.CO;2-M

Kay CD (2006) Aspects of anthocyanin absorption, metabolism and pharmacokinetics in humans. Nutr Res Rev 19(01):137-146

Kueny-Stotz M, Isorez G, Chassaing S, Brouillard R (2007) Straightforward synthesis of highly hydroxylated phloroglucinol-type 3-deoxyanthocyanidins. Synlett 2007(7):1067-1070. doi:10.1055/s-2007-977433

Kueny-Stotz M, Chassaing S, Brouillard R, Nielsen M, Goeldner M (2008) Flavylium salts as in vitro precursors of potent ligands to brain GABA-A receptors. Bioorg Med Chem Lett 18(17):4864-4867. doi:10.1016/j. bmcl.2008.07.107

Kuhnert N, Clifford MN, Radenac A-G (2001) Boron trifluoride-etherate mediated synthesis of 3-desoxyanthocyanidins including a total synthesis of tricetanidin from black tea. Tetrahedron Lett 42(52):9261-9263. doi:10.1016/S0040-4039(01)01975-X

Mas T (2003) A new and convenient one-stepSynthesis of the natural 3-deoxyanthocyanidins apigeninidinand luteolinidin chlorides from 2,4,6-triacetoxybenzaldehyde. Synthesis 2003(12):1878-1880. doi:10.105 5/s-2003-40982

Michaelidis C, Wizinger R (1951) Beitrag zur Kenntnis der 2-Aryl-benzopyryliumsalze. Helvetica Chimica Acta 34(6):1761-1770. doi:10.1002/ hlca.19510340608
Moncada MC, Pina F, Roque A, Parola AJ, Maestri M, Balzani V (2004) Tuning the photochromic properties of a flavylium compound by pH. Eur J Org Chem 2004(2):304-312. doi:10.1002/ejoc.200300508

Mora-Soumille N, Al Bittar S, Rosa M, Dangles O (2013) Analogs of anthocyanins with a 3',4'-dihydroxy substitution: synthesis and investigation of their acid-base, hydration, metal binding and hydrogen-donating properties in aqueous solution. Dye Pigment 96(1):7-15. doi:10.1016/j. dyepig.2012.07.006

Pina F, Roque A, Melo MJ, Maestri M, Belladelli L, Balzani V (1998) Multistate/multifunctional molecular-level systems: light and $\mathrm{pH}$ switching between the various forms of a synthetic flavylium salt. Chem Eur J 4(7):1184-1191. doi:10.1002/ (SICI)1521-3765(19980710)4:7<1184:AID-CHEM1184>3.0.CO;2-6

Pina F, Melo MJ, Laia CAT, Parola AJ, Lima JC (2012) Chemistry and applications of flavylium compounds: a handful of colours. Chem Soc Rev 41(2):869908. doi:10.1039/C1CS15126F

Pojer E, Mattivi F, Johnson D, Stockley CS (2013) The case for anthocyanin consumption to promote human health: a review. Compr Rev Food Sci Food Saf 12(5):483-508. doi:10.1111/1541-4337.12024

Pulido R, Bravo L, Saura-Calixto F (2000) Antioxidant activity of dietary polyphenols as determined by a modified ferric reducing/antioxidant power assay. J Agric Food Chem 48(8):3396-3402. doi:10.1021/jf9913458

Sato S, Watanabe T, Kumagai H, Kitamura N, Matsuba S, Kumazawa T, Onodera J-I, Suzuki M (1999) Convenient synthesis of 1,6,7,8-substituted 2-(3',4'-substituted-phenyl)-4-quinolones via a 4-ethoxyflavylium salt. J Heterocycl Chem 36(5):1189-1193. doi:10.1002/jhet.5570360513

Sochor J, Ryvolova M, Krystofova O, Salas P, Hubalek J, Adam V, Trnkova L, Havel L, Beklova M, Zehnalek J, Provaznik I, Kizek R (2010) Fully automated spectrometric protocols for determination of antioxidant activity: advantages and disadvantages. Molecules 15(12):8618-8640

Sun L-L, Gao W, Zhang M-M, Li C, Wang A-G, Su Y-L, Ji T-F (2014) Composition and antioxidant activity of the anthocyanins of the fruit of Berberis heteropoda Schrenk. Molecules 19(11):19078

Sweeny JG, lacobucci GA (1983) Effect of substitution on the stability of 3-deoxyanthocyanidins in aqueous solutions. J Agric Food Chem 31(3):531-533. doi:10.1021/jf00117a017

Thaipong K, Boonprakob U, Crosby K, Cisneros-Zevallos L, Hawkins Byrne D (2006) Comparison of ABTS, DPPH, FRAP, and ORAC assays for estimating antioxidant activity from guava fruit extracts. J Food Compos Anal 19(6-7):669-675. doi:10.1016/j.jfca.2006.01.003

Wallace TC (2011) Anthocyanins in cardiovascular disease. Adv Nutr: Int Rev J 2(1):1-7

Wang L-S, Stoner GD (2008) Anthocyanins and their role in cancer prevention. Cancer Lett 269(2):281-290. doi:10.1016/j.canlet.2008.05.020

Zafra-Stone S, Yasmin T, Bagchi M, Chatterjee A, Vinson JA, Bagchi D (2007) Berry anthocyanins as novel antioxidants in human health and disease prevention. Mol Nutr Food Res 51(6):675-683. doi:10.1002/ mnfr.200700002

\section{Submit your manuscript to a SpringerOpen ${ }^{\circ}$ journal and benefit from:}

- Convenient online submission

- Rigorous peer review

- Immediate publication on acceptance

- Open access: articles freely available online

- High visibility within the field

- Retaining the copyright to your article

Submit your next manuscript at springeropen.com 